\title{
Association of Autoimmunity and Parvovirus B19 Infection among Spontaneous Miscarriage Women in Erbil / Iraq
}

\author{
Nyan J. Mohammed \\ Department of Pathological Analysis /College of Science/ University of Knowledge \\ E-mail: nyan.mohammed@knu.edu.iq
}

(Received 9\10\2019; Accepted 19\1\2020)

DOI: $\underline{10.33899 / \text { rjs.2020.164472 }}$

\begin{abstract}
The study was conducted from January 2016 to January 2017 at Maternity Teaching Hospital in Erbil city/ Iraq. One hundred and forty women who experienced spontaneous abortions were selected according to inclusion and exclusion criteria and forty normal pregnant women as a control group. Serum from patients and control group subjected for assessment of anticardiolipin IgM, antiphospholipid IgM, Parvovirus B19 IgG and IgM using enzyme linked immune-sorbent assay technique. Prevalence of positive Parvovirus B19 IgG and IgM, anticardiolipin IgM and antiphospholipid IgM, in aborted women was higher than that observed in non-aborted women (control group). Women with the highest frequency of spontaneous abortion found at age group 27-34 year. More frequent of previous spontaneous abortion was 1-2 abortion at the $1^{\text {st }}$ trimester of gestational period. Anticardiolipin antibody and antiphospholipid antibody production trigged by viral infection, and have role in spontaneous abortion in pregnant women.
\end{abstract}

Keywords: Parvovirus Infections, ELISA, Anticardiolipin, Antiphospholipid, Autoimmunity.

\section{INTRODUCTION}

Spontaneous abortion means loss of an embryo or fetus before the $24^{\text {th }}$ week of pregnancy. Abortion is considered not only a major reproductive health matter, but also as a health factor for mother's well-being which also threaten mothers lives and comfort (Baltaci and Baltaci, 2016). The role of viral infection in the pathogenesis of spontaneous abortion is controversial (Chopra et al., 2004).

The usual way in which the fetus is infected is by transplacental spread after maternal infection in which the organism circulates in the mother's blood. These infections, acquired in utero, can be severe enough to cause fetal loss or can result in intrauterine growth restriction, prematurity, or chronic postnatal infection (Christiansen et al., 2008). According to (Ali et al., 2012) certain immunological changes during pregnancy can led to autoimmune diseases.

Antiphospholipid syndrome (APS) is a systemic autoimmune disease characterized by various clinical manifestations (the most characteristic are thromboses and pregnancy morbidity) in the presence of elevated levels of certain antiphospholipid antibodies. Antiphospholipid antibodies, including lupus anticoagulant (LA) and anticardiolipin antibodies (ACL), are auto antibodies that bind to cardiolipin and/or $\beta 2$ glycoprotein I ( $\beta 2$ GP-I) bound to phospholipids (Mackay et al., 2014). It was reported that antiphospholipid antibodies (APL) and ACL interfere with fetal implantation, which related to the pathological mechanism responsible for recurrent abortions (Clark et al., 2012). Viral 
infections were most commonly implicated as an infectious trigger for induction of APL (Harel et al., 2005). Parvovirus-B19 virus (Par.B19) is the most commonly implicated pathogen in the development of fetal loss (Alanen et al., 2005). The greatest risk to the fetus occurs in the gestational age ranging between weeks 10 and 20, which coincides with the development of erythroid precursors: in fact, the virus can infect erythroid precursors inhibiting erythropoiesis and cause a non-immune hydrops (Chisaka et al., 2006).

\section{MATERIALS AND METHODS}

This case control study was carried out in Maternity Teaching Hospital in Erbil city/ Iraq. One hundred and forty women who experienced spontaneous abortion and 40 normal pregnant women as a control group who attended the Maternity Teaching Hospital, were included in this study. The period of this study was 1 year from January 2016 to January 2017.

A total of one hundred and forty blood samples were collected from the aborted women and forty blood samples were collected from normal pregnant women for detection of IgM of ACL and APL, IgM and $\mathrm{IgG}$ for Par.B19 by using Enzyme linked immunosorbent assay (ELISA). Blood sampling was performed by withdrawing $5 \mathrm{ml}$ venous blood from each patient and control group using a disposable syringe (vein puncture technique) and collected in gel vacuum tubes, allowed to clot at room temperature, then centrifuged at 3000 rounds per minute for 15 minutes, the sera obtained were dispensed into three labeled and sterile Eppendrof tubes and stored at $-20 \mathrm{C}^{\mathrm{O}}$ at Maternity Teaching Hospital laboratory to be used for serological tests.

Serological: Parvovirus B19 IgM and IgG Enzyme Immunoassay Test Kit was used Catalog Number: MBS494186 and MBS494069 from MyBiosource, Inc. (USA), APL ELISA Kit and ACL ELISA Kit IgM Enzyme Immunoassay Test Kit was used Catalog Number: 3224 and 3204 from AESKU.DIAGNOSTICS GmbH \& Co. KG (Germany).

Statistical analysis: Data were entered and analyzed using statistical package for social science (SPSS), version 19.0. The statistical techniques applied to analyze the data, including standard deviation, mean, maximum and minimum, while the differences were evaluated by t-test. $\mathrm{P}$ value $\leq 0.05$ and $\mathrm{P}$ value $<0.01$ were set as statistically significant.

\section{RESULTS AND DISCUSSIONS}

The ages of the control subjects ranged from 18-44 years with mean of $30.6 \pm 1.13$ years. Number of abortion were $1.8 \pm 0.16$ and the mean value of their gestational period were $1.1 \pm 0.05$; where as the ages of the aborted subjects ranged from19-49 years with mean of $31.64 \pm 0.55$ years and the mean value of number of abortion and their gestational period were $2.1 \pm 0.11$ and $1.44 \pm 0.05$ respectively. Non-significant differences in the mean values of age, vaccination, child with birth defect and ACL IgM were observed between control and aborted women, while significant difference was found between the groups in number of gestation period and APL IgM. Significant differences found between the groups regarding viral screen for IgG and IgM, (Table 1). 
Table 1: Demographic comparison between control group and aborted women in regards to clinical characteristics, certain autoimmunity antibodies and viral infection serological markers

\begin{tabular}{|c|c|c|c|c|c|}
\hline \multicolumn{3}{|c|}{ Characteristics } & $\begin{array}{l}\text { Control Group } \\
\text { No. }(40)(\%)\end{array}$ & $\begin{array}{l}\text { Aborted women } \\
\text { No. (140) (\%) }\end{array}$ & P. value \\
\hline \multirow{2}{*}{\multicolumn{2}{|c|}{ Vaccination during pregnancy No. }} & Yes & $40(100.0)$ & $136(97.1)$ & \multirow[t]{2}{*}{$0.362^{\mathrm{NS}}$} \\
\hline & & No & $0(0.0)$ & $4(2.8)$ & \\
\hline \multirow{2}{*}{\multicolumn{2}{|c|}{ Child with birth defect No. }} & Yes & $0(0.0)$ & $6(4.2)$ & \multirow[t]{2}{*}{$0.216^{\mathrm{NS}}$} \\
\hline & & No & $40(100.0)$ & $134(95.7)$ & \\
\hline \multirow[t]{2}{*}{ ACL No. } & \multirow[t]{2}{*}{$\operatorname{IgM}$} & Negative & $20(50.0)$ & $50(35.7)$ & \multirow[t]{2}{*}{$0.074^{\mathrm{NS}}$} \\
\hline & & Positive & $20(50.0)$ & $90(64.2)$ & \\
\hline \multirow[t]{2}{*}{ APL No. } & \multirow[t]{2}{*}{ IgM } & Negative & $38(95.0)$ & $38(27.1)$ & \multirow[t]{2}{*}{$0.001 * *$} \\
\hline & & Positive & $2(5.0)$ & $102(72.8)$ & \\
\hline \multirow[t]{4}{*}{ Par.B19 No. } & \multirow[t]{2}{*}{$\mathrm{IgG}$} & Negative & $32(80.0)$ & $76(54.2)$ & \multirow[t]{2}{*}{$0.002 * *$} \\
\hline & & Positive & $8(20.0)$ & $64(45.7)$ & \\
\hline & \multirow[t]{2}{*}{ IgM } & Negative & $14(35.0)$ & $72(51.4)$ & \multirow[t]{2}{*}{$0.048^{*}$} \\
\hline & & Positive & $26(65.0)$ & $68(48.5)$ & \\
\hline
\end{tabular}

$* \mathrm{P}$ value $<0.05$ : significant, ** $\mathrm{P}$ value $<0.01$ : Highly significant, NS: non-significant

The results in (Table 2) shows the mean values of gestational period for -ve IgG of Par.B19 were $31.02 \pm 0.75$ and for + ve $\mathrm{IgG}$ of Par.B19 were 32.37 \pm 0.81 . And the mean values of number of abortion for - ve IgG of Par.B19 were 2.05 \pm 0.12 and for + ve IgG of Par.B19 were 2.15 \pm 0.17 . Non-significant differences in mean values and frequency of clinical characteristics found between negative and positive IgG of Par.B19. APL IgM, showed significant differences, while non-significant differences of ACL IgM found between the groups.

Table 2: Relationship of gestational period, clinical characteristics, ACL, APL and viral immunoglobulin with negative and positive IgG of Par.B19 among aborted women

\begin{tabular}{|c|c|c|c|c|c|}
\hline \multicolumn{3}{|c|}{ Characteristics } & $\begin{array}{l}\text {-ve IgG of } \\
\text { Par.B19 } \\
\text { No. }(76)(\%)\end{array}$ & $\begin{array}{l}\text { + ve IgG of } \\
\text { Par.B19 } \\
\text { No. (64) }(\%)\end{array}$ & P. value \\
\hline \multirow{3}{*}{\multicolumn{2}{|c|}{ Gestational period of abortion No. }} & $1^{\text {st }}$ trimester & $50(65.7)$ & $34(53.1)$ & \multirow[t]{3}{*}{$0.18^{\mathrm{NS}}$} \\
\hline & & $2^{\text {nd }}$ trimester & $22(28.9)$ & $28(43.7)$ & \\
\hline & & $3^{\text {rd }}$ trimester & $4(5.2)$ & $2(3.1)$ & \\
\hline \multirow{2}{*}{\multicolumn{2}{|c|}{ Vaccination during pregnancy No. }} & Yes & $72(94.7)$ & $64(100.0)$ & \multirow[t]{2}{*}{$0.084^{\mathrm{NS}}$} \\
\hline & & No & $4(5.2)$ & $0(0.0)$ & \\
\hline \multirow{2}{*}{\multicolumn{2}{|c|}{ Child with birth defect No. }} & Yes & $3(3.9)$ & $3(4.6)$ & \multirow[t]{2}{*}{$0.575^{\mathrm{NS}}$} \\
\hline & & No & $73(96.0)$ & $61(95.3)$ & \\
\hline \multirow[t]{2}{*}{ ACL No. } & \multirow[t]{2}{*}{$\operatorname{IgM}$} & Negative & $24(31.5)$ & $26(40.6)$ & \multirow[t]{2}{*}{$0.175^{\mathrm{NS}}$} \\
\hline & & Positive & $52(68.4)$ & $38(59.3)$ & \\
\hline \multirow[t]{2}{*}{ APL No. } & \multirow[t]{2}{*}{$\operatorname{IgM}$} & Negative & $62(81.5)$ & $40(62.5)$ & \multirow[t]{2}{*}{$0.01 * *$} \\
\hline & & Positive & $14(18.4)$ & $24(37.5)$ & \\
\hline \multirow[t]{2}{*}{ Par.B19 No. } & \multirow[t]{2}{*}{$\operatorname{IgM}$} & Negative & $42(55.2)$ & $30(46.8)$ & \multirow[t]{2}{*}{$0.206^{\mathrm{NS}}$} \\
\hline & & Positive & $34(44.7)$ & $34(53.1)$ & \\
\hline
\end{tabular}

** $\mathrm{P}$ value $<0.01$ : Highly significant, NS: non-significant.

Table (3) shows the mean values of age for - ve IgM of Par.B19 were $31.33 \pm 0.83$ and for + ve IgM of Par.B19 were31.97 \pm 0.71 . And the mean values of number of abortion for - ve IgM of Par.B19 were $1.75 \pm 0.11$ and for + ve IgM of Par.B19 were $2.47 \pm 0.17$. 
Significant differences in mean value and frequency of number of abortion and gestational period, while other clinical characteristics found non-significant differences between negative and positive IgM of Par.B19.ACL IgM, showed significant differences, while non-significant differences of APL IgM found between the groups.

Table 3: Relationship of gestational period of abortion, clinical characteristics, ACL, APL and viral immunoglobulin with negative and positive IgM of Par.B19 among women

\begin{tabular}{|c|c|c|c|c|}
\hline \multicolumn{2}{|l|}{ Characteristics } & $\begin{array}{l}\text {-ve IgM of } \\
\text { Par.B19 } \\
\text { No. (72) (\%) }\end{array}$ & $\begin{array}{l}+ \text { ve IgM of } \\
\text { Par.B19 } \\
\text { No. }(68)(\%)\end{array}$ & P. value \\
\hline \multirow{3}{*}{ Gestational period of abortion No. } & $1^{\text {st }}$ trimester & $40(55.5)$ & $44(64.7)$ & \multirow[t]{3}{*}{$0.007 * *$} \\
\hline & $2^{\text {nd }}$ trimester & $32(44.4)$ & $18(26.4)$ & \\
\hline & $3^{\text {rd }}$ trimester & $0(0.0)$ & $6(8.8)$ & \\
\hline \multirow[t]{2}{*}{ Vaccination during pregnancy No. } & Yes & $70(97.2)$ & $66(97.0)$ & \multirow[t]{2}{*}{$0.668^{\mathrm{NS}}$} \\
\hline & No & $2(2.7)$ & $2(2.9)$ & \\
\hline \multirow[t]{2}{*}{ Child with birth defect No. } & Yes & $6(8.3)$ & $0(0.0)$ & \multirow[t]{2}{*}{$0.017^{*}$} \\
\hline & No & $66(91.6)$ & $68(68.0)$ & \\
\hline \multirow[t]{2}{*}{ ACL No. } & Negative & $18(25.0)$ & $32(47.0)$ & \multirow[t]{2}{*}{$0.005 * *$} \\
\hline & Positive & $54(75.0)$ & $36(52.9)$ & \\
\hline \multirow[t]{2}{*}{ APL No. } & Negative & $55(76.3)$ & $47(69.1)$ & \multirow[t]{2}{*}{$0.219^{\mathrm{NS}}$} \\
\hline & Positive & $17(23.6)$ & $21(30.8)$ & \\
\hline \multirow[t]{2}{*}{ Par.B19 No. } & Negative & $42(58.3)$ & $34(50.0)$ & \multirow[t]{2}{*}{$0.206^{\mathrm{NS}}$} \\
\hline & Positive & $30(41.6)$ & $34(50.0)$ & \\
\hline
\end{tabular}

$* \mathrm{P}$ value < 0.05: significant, $* * \quad \mathrm{P}$ value < 0.01: Highly significant, NS: non-significant.

Women with experienced spontaneous abortion are categorized into three groups according to their ages (Table 4). The mean value of the number of abortions for the age ranged from 19-26 years were $1.91 \pm 0.17$ while for the age ranged from 27-34 years and age $\geq 35$ year were 2.00 \pm 0.14 and $2.43 \pm 0.21$ respectively and the mean values of gestation period, vaccination and child with birth defect showed non-significant differences. Non-significant differences revealed between age groups, for ACL IgM, Par.B19 for both IgG; IgM while significant differences for APL IgM.

Table 4: Relationship of clinical characteristics, certain immunoglobulin of ACL, APL and viral infection serological markers among aborted women according to age

\begin{tabular}{|c|c|c|c|c|c|c|}
\hline \multicolumn{3}{|c|}{ Characteristics } & $\begin{array}{l}\text { Age 19-26 } \\
\text { No. }(28)(\%)\end{array}$ & $\begin{array}{l}\text { Age } 27-34 \\
\text { No. }(66)(\%)\end{array}$ & $\begin{array}{l}\text { Age } \geq 35 \\
\text { No. }(46)(\%)\end{array}$ & P. value \\
\hline \multirow{3}{*}{\multicolumn{2}{|c|}{ Gestational period of abortion No. }} & $1^{\text {st }}$ trimester & $18(64.2)$ & $42(64.0)$ & $24(52.1)$ & \multirow[t]{3}{*}{$0.599^{\mathrm{NS}}$} \\
\hline & & $2^{\text {nd }}$ trimester & $8(28.5)$ & $22(33.3)$ & $20(43.4)$ & \\
\hline & & $3^{\text {rd }}$ trimester & $2(7.1)$ & $2(3.03)$ & $2(4.3)$ & \\
\hline \multirow{2}{*}{\multicolumn{2}{|c|}{ Vaccination during pregnancy No. }} & Yes & $28(100)$ & $62(94.0)$ & $46(100.0)$ & \multirow[t]{2}{*}{$0.099^{\mathrm{NS}}$} \\
\hline & & No & $0(0.0)$ & $4(6.06)$ & $0(0.0)$ & \\
\hline \multirow{2}{*}{\multicolumn{2}{|c|}{ Child with birth defect No. }} & Yes & $0(0.0)$ & $2(3.03)$ & $4(8.6)$ & \multirow[t]{2}{*}{$0.158^{\mathrm{NS}}$} \\
\hline & & No & $28(100.0)$ & $64(96.9)$ & $42(91.3)$ & \\
\hline \multirow[t]{2}{*}{ ACL No. } & \multirow[t]{2}{*}{$\operatorname{IgM}$} & Negative & $6(21.4)$ & $24(36.3)$ & $19(41.3)$ & \multirow[t]{2}{*}{$0.21^{\mathrm{NS}}$} \\
\hline & & Positive & $22(78.5)$ & $42(63.6)$ & $27(58.6)$ & \\
\hline \multirow[t]{2}{*}{ APL No. } & \multirow[t]{2}{*}{$\operatorname{IgM}$} & Negative & $26(93.0)$ & $42(63.6)$ & $34(73.9)$ & \multirow[t]{2}{*}{$0.01 * *$} \\
\hline & & Positive & $2(7.1)$ & $24(36.3)$ & $12(26.08)$ & \\
\hline \multirow[t]{4}{*}{ Par.B19 No. } & \multirow[t]{2}{*}{ IgG } & Negative & $18(64.2)$ & $38(57.5)$ & $20(43.4)$ & \multirow[t]{2}{*}{$0.167^{\mathrm{NS}}$} \\
\hline & & Positive & $10(35.7)$ & $28(42.4)$ & $26(56.5)$ & \\
\hline & \multirow[t]{2}{*}{ IgM } & Negative & $14(50.0)$ & $34(51.5)$ & $22(47.8)$ & \multirow[t]{2}{*}{$0.873^{\mathrm{NS}}$} \\
\hline & & Positive & $12(42.8)$ & $32(48.4)$ & $24(52.1)$ & \\
\hline
\end{tabular}

** $\mathrm{P}$ value < 0.01: Highly significant, NS: non-significant. 
Women with spontaneous abortion classified according to the number of abortion into three groups (Table 5). The mean value of age according to the number of abortion 1-2 abortions were $31.4 \pm 0.65$, for 3-4 abortions and 5-6 abortions were $31.66 \pm 1.19$ and 34.0 \pm 1.87 respectively. Nonsignificant differences found between the groups in term of age, vaccination and child with birth defect. While significant differences found in term of gestational period and Par.B19 IgG and IgM.

Table 5: Relationship of gestational period of abortion, clinical characteristics, certain immunoglobulin of ACL, APL and viral infection markers among aborted women according to number of abortions

\begin{tabular}{|c|c|c|c|c|c|c|}
\hline \multicolumn{3}{|c|}{ Characteristics } & $\begin{array}{l}\text { 1-2 abortion } \\
\text { No. }(100)(\%)\end{array}$ & $\begin{array}{l}\text { 3-4 abortion } \\
\text { No. }(30)(\%)\end{array}$ & $\begin{array}{l}\text { 5-6 abortion } \\
\text { No. }(10)(\%)\end{array}$ & P. value \\
\hline \multirow{3}{*}{\multicolumn{2}{|c|}{$\begin{array}{l}\text { Gestational period of } \\
\text { abortion No. }\end{array}$}} & $1^{\text {st }}$ trimester & $64(64.0)$ & $18(60.0)$ & $2(20.0)$ & \multirow[t]{3}{*}{$0.018 *$} \\
\hline & & $2^{\text {nd }}$ trimester & $30(30.0)$ & $12(40.0)$ & $8(80.0)$ & \\
\hline & & $3^{\text {rd }}$ trimester & $6(6.0)$ & $0(0.0)$ & $0(0.0)$ & \\
\hline \multirow{2}{*}{\multicolumn{2}{|c|}{$\begin{array}{l}\text { Vaccination during pregnancy } \\
\text { No. }\end{array}$}} & Yes & $96(96.0)$ & $30(30.0)$ & $10(100.0)$ & \multirow[t]{2}{*}{$0.439^{\mathrm{NS}}$} \\
\hline & & No & $4(4.0)$ & $0(0.0)$ & $0(0.0)$ & \\
\hline \multirow{2}{*}{\multicolumn{2}{|c|}{ Child with birth defect No. }} & Yes & $4(4.0)$ & $2(6.6)$ & $0(0.0)$ & \multirow[t]{2}{*}{$0.643^{\mathrm{NS}}$} \\
\hline & & No & $96(96.0)$ & $28(93.3)$ & $10(100.0)$ & \\
\hline \multirow[t]{2}{*}{ ACL No. } & \multirow[t]{2}{*}{$\operatorname{IgM}$} & Negative & $37(37.0)$ & $11(36.6)$ & $2(20.0)$ & \multirow[t]{2}{*}{$0.56^{\mathrm{NS}}$} \\
\hline & & Positive & $63(63.0)$ & $19(63.3)$ & $8(80.0)$ & \\
\hline \multirow[t]{2}{*}{ APL No. } & \multirow[t]{2}{*}{$\operatorname{IgM}$} & Negative & $74(74.0)$ & $22(73.3)$ & $6(60.0)$ & \multirow[t]{2}{*}{$0.636^{\mathrm{NS}}$} \\
\hline & & Positive & $26(26.0)$ & $8(26.6)$ & $4(40.0)$ & \\
\hline \multirow{4}{*}{ Par.B19 No. } & \multirow[t]{2}{*}{$\mathrm{IgG}$} & Negative & $52(52.0)$ & $22(73.3)$ & $2(20.0)$ & \multirow[t]{2}{*}{$0.009 * *$} \\
\hline & & Positive & $48(48.0)$ & $8(26.6)$ & $8(80.0)$ & \\
\hline & \multirow[t]{2}{*}{$\operatorname{IgM}$} & Negative & $58(58.0)$ & $12(40.0)$ & $2(20.0)$ & \multirow[t]{2}{*}{$0.027 *$} \\
\hline & & Positive & $42(42.0)$ & $18(60.0)$ & $8(80.0)$ & \\
\hline
\end{tabular}

* $\mathrm{P}$ value < 0.05: significant, ** $\mathrm{P}$ value < 0.01: Highly significant, NS: non-significant.

The result have shown the mean values of gestational period for the 1 st trimester were $31.28 \pm 0.66$ and for the 2 nd trimester and 3rd trimester were 32.32 \pm 1.02 and 31.0 \pm 2.75 respectively. And the mean values of number of abortion for the1st trimester were $1.95 \pm 0.11$ and for the 2 nd trimester and 3rd trimester were2.4 \pm 0.22 and $1.66 \pm 0.21$ respectively. Gestational period of abortion with clinical characteristics showed non-significant differences. Par. B19I gM revealed statistically significant differences, while ACL, APL found statistically non-significant frequency (Table 6). 
Table 6: Relationship of clinical characteristics, certain immunoglobulin of ACL, APL and viral infection markers among aborted women according to gestational period

\begin{tabular}{|c|c|c|c|c|c|c|}
\hline \multicolumn{3}{|c|}{ Characteristics } & $\begin{array}{l}1^{\text {st }} \text { trimester } \\
\text { No. }(84)(\%)\end{array}$ & $\begin{array}{l}2^{\text {nd }} \text { trimester } \\
\text { No. }(50)(\%)\end{array}$ & $\begin{array}{l}3^{\text {rd }} \text { trimester } \\
\text { No. }(6)(\%)\end{array}$ & P. value \\
\hline \multirow{2}{*}{\multicolumn{2}{|c|}{ Vaccination during pregnancy No. }} & Yes & $80(95.2)$ & $50(100.0)$ & $6(100.0)$ & \multirow[t]{2}{*}{$0.253^{\mathrm{NS}}$} \\
\hline & & No & $4(4.7)$ & $0(0.0)$ & $0(0.0)$ & \\
\hline \multirow{2}{*}{\multicolumn{2}{|c|}{ Child with birth defect No. }} & Yes & $6(7.1)$ & $0(0.0)$ & $0(0.0)$ & \multirow[t]{2}{*}{$0.124^{\mathrm{NS}}$} \\
\hline & & No & $78(92.8)$ & $50(100.0)$ & $6(100.0)$ & \\
\hline \multirow[t]{2}{*}{ ACL No. } & \multirow[t]{2}{*}{$\operatorname{IgM}$} & Negative & $28(33.3)$ & $20(40.0)$ & $2(33.3)$ & \multirow[t]{2}{*}{$0.733^{\mathrm{NS}}$} \\
\hline & & Positive & $56(66.6)$ & $30(60.0)$ & $4(66.6)$ & \\
\hline \multirow[t]{2}{*}{ APL No. } & \multirow[t]{2}{*}{$\operatorname{IgM}$} & Negative & $18(21.4)$ & $32(64.0)$ & $4(66.6)$ & \multirow[t]{2}{*}{$0.175^{\mathrm{NS}}$} \\
\hline & & Positive & $66(78.5)$ & $18(36.0)$ & $2(33.3)$ & \\
\hline \multirow[t]{4}{*}{ Par.B19 No. } & \multirow[t]{2}{*}{ IgG } & Negative & $50(59.5)$ & $22(44.0)$ & $4(66.6)$ & \multirow[t]{2}{*}{$0.18^{\mathrm{NS}}$} \\
\hline & & Positive & $34(40.4)$ & $28(56.0)$ & $2(33.3)$ & \\
\hline & \multirow[t]{2}{*}{$\operatorname{IgM}$} & Negative & $40(47.6)$ & $32(64.0)$ & $0(0.0)$ & \multirow[t]{2}{*}{$0.007 * *$} \\
\hline & & Positive & $44(52.3)$ & $18(36.0)$ & $6(100.0)$ & \\
\hline
\end{tabular}

** P value < 0.01: Highly significant, NS: non-significant.

Table (7) shows statistically significant differences in frequency of gestational period of abortion and Par.B19 between negative and positive IgM of ACL among aborted women, while other clinical characteristics and the immunoglobulin of APL showed non-significant differences.

The mean values of age for - ve IgM of ACL were 32.64 \pm 0.81 and for + ve IgM of ACL were $31.08 \pm 0.72$. And the mean values of number of abortion for - ve IgM of ACL were $2.0 \pm 0.15$ and for + ve IgM of ACL were2.15 \pm 0.14 .

Table 7: Relationship of gestational period of abortion, clinical characteristics, APL and viral immunoglobulin with negative and positive IgM of ACL among aborted women

\begin{tabular}{|c|c|c|c|c|c|}
\hline \multicolumn{3}{|c|}{ Characteristics } & $\begin{array}{l}\text {-ve IgM of } \\
\text { ACL } \\
\text { No. }(50)(\%)\end{array}$ & $\begin{array}{l}\text { + ve IgM of ACL } \\
\text { No. }(90)(\%)\end{array}$ & P. value \\
\hline \multirow{3}{*}{\multicolumn{2}{|c|}{ Gestational period of abortion No. }} & $1^{\text {st }}$ trimester & $28(56.0)$ & $54(60.0)$ & \multirow[t]{3}{*}{$0.642^{\mathrm{NS}}$} \\
\hline & & $2^{\text {nd }}$ trimester & $20(40.0)$ & $30(33.3)$ & \\
\hline & & $3^{\text {rd }}$ trimester & $2(4.0)$ & $6(6.6)$ & \\
\hline \multirow{2}{*}{\multicolumn{2}{|c|}{ Vaccination during pregnancy No. }} & Yes & $46(92.0)$ & $90(100.0)$ & \multirow[t]{2}{*}{$0.015^{*}$} \\
\hline & & No & $4(8.0)$ & $0(0.0)$ & \\
\hline \multirow{2}{*}{\multicolumn{2}{|c|}{ Child with birth defect No. }} & Yes & $0(0.0)$ & $6(6.6)$ & \multirow[t]{2}{*}{$0.66^{\mathrm{NS}}$} \\
\hline & & No & $50(100.0)$ & $84(93.3)$ & \\
\hline \multirow[t]{2}{*}{ APL No. } & \multirow[t]{2}{*}{$\operatorname{IgM}$} & Negative & $36(72.0)$ & $66(73.3)$ & \multirow[t]{2}{*}{$0.508^{\mathrm{NS}}$} \\
\hline & & Positive & $14(28.0)$ & $24(26.6)$ & \\
\hline \multirow[t]{4}{*}{ Par.B19 No. } & \multirow[t]{2}{*}{$\mathrm{IgG}$} & Negative & $24(48.0)$ & $52(57.7)$ & \multirow[t]{2}{*}{$0.175^{\mathrm{NS}}$} \\
\hline & & Positive & $26(52.0)$ & $38(42.2)$ & \\
\hline & \multirow[t]{2}{*}{$\operatorname{IgM}$} & Negative & $18(36.0)$ & $54(60.0)$ & \multirow[t]{2}{*}{$0.005 * *$} \\
\hline & & Positive & $32(64.0)$ & $36(40.0)$ & \\
\hline
\end{tabular}

$* \mathrm{P}$ value < 0.05: significant, $* * \mathrm{P}$ value < 0.01: Highly significant, NS: non-significant.

While (Table 8) shows

statistically significant differences in frequency of gestational period of abortion, ACL IgM, Par.B19 between negative and positive IgM of APL among aborted women. The mean values of age for $-\mathrm{ve}$ $\operatorname{IgM}$ of APL were $31.07 \pm 0.67$ and for + ve $\operatorname{IgM}$ of APL were $33.15 \pm 0.88$. And the mean values of number of abortion for - ve IgM of APL were2.01 \pm 0.12 and for + ve IgM of APL were2.31 \pm 0.22 . 
Association of Autoimmunity and Parvovirus.....................

Table 8: Relationship of gestational period of abortion, clinical characteristics, ACL and viral immunoglobulin with negative and positive IgM of APL among aborted women.

\begin{tabular}{|c|c|c|c|c|c|}
\hline \multicolumn{3}{|c|}{ Characteristics } & $\begin{array}{l}\text {-ve IgM of APL } \\
\text { No. }(102)(\%)\end{array}$ & $\begin{array}{l}\text { + ve IgM of APL } \\
\text { No. }(38)(\%)\end{array}$ & P. value \\
\hline \multirow{3}{*}{\multicolumn{2}{|c|}{ Gestational period of abortion No. }} & $1^{\mathrm{st}}$ trimester & $66(64.7)$ & $19(50.0)$ & \multirow{3}{*}{$0.0001 * *$} \\
\hline & & $2^{\text {nd }}$ trimester & $32(31.3)$ & 17(44.7) & \\
\hline & & $3^{\text {rd }}$ trimester & $4(3.9)$ & $2(5.2)$ & \\
\hline \multirow{2}{*}{\multicolumn{2}{|c|}{ Vaccination during pregnancy No. }} & Yes & $100(98.0)$ & $36(94.7)$ & \multirow[t]{2}{*}{$0.297^{\mathrm{NS}}$} \\
\hline & & No & $2(1.9)$ & $2(5.2)$ & \\
\hline \multirow{2}{*}{\multicolumn{2}{|c|}{ Child with birth defect No. }} & Yes & $4(3.9)$ & $2(5.2)$ & \multirow[t]{2}{*}{$0.519^{\mathrm{NS}}$} \\
\hline & & No & $98(96.0)$ & $36(94.7)$ & \\
\hline \multirow[t]{2}{*}{ ACL No. } & \multirow[t]{2}{*}{$\operatorname{IgM}$} & Negative & $36(35.2)$ & $14(36.8)$ & \multirow[t]{2}{*}{$0.508^{\mathrm{NS}}$} \\
\hline & & Positive & $66(64.7)$ & $24(63.1)$ & \\
\hline \multirow[t]{4}{*}{ Par.B19 No. } & \multirow[t]{2}{*}{$\mathrm{IgG}$} & Negative & $62(60.7)$ & $14(36.8)$ & \multirow[t]{2}{*}{$0.01 * *$} \\
\hline & & Positive & $40(39.2)$ & $24(63.1)$ & \\
\hline & \multirow[t]{2}{*}{$\operatorname{IgM}$} & Negative & $56(54.9)$ & $16(42.1)$ & \multirow[t]{2}{*}{$0.124^{\mathrm{NS}}$} \\
\hline & & Positive & $46(45.0)$ & $22(57.8)$ & \\
\hline
\end{tabular}

** $\mathrm{P}$ value < 0.01: Highly significant, NS: non-significant .

In the present study a total of 140 women with previous spontaneous abortion were participated, their mean age was 31.64 years range from 19-49 years, which is in consistent with the study done by Pokale and Khadke (2016), in which 400 aborted women participated in the study their age ranged from 19-50 years. Perinatal outcomes from infections during pregnancy can range from no effect to pregnancy loss by spontaneous abortion to fetal infection with resulting congenital viral syndromes (Silasi et al., 2015). The clinical symptoms of neonatal infections differ depending on the viral agent and gestational age at the time of exposure (Al-Taie et al., 2018). The placenta forms a barrier between mother and fetus during the first trimester of pregnancy that protects the fetus from the humoral and cellular mediated immunological response. Although, the fetus gets immunity from mother, they are seriously infected by these viruses due to lack of immunity after the first trimester of pregnancy. All the infections have their own causative agent and generally they spread through poor hygienic conditions, contaminated blood (Pizzo, 2011). Par.B19 infection in a pregnant woman, followed by transplacental transmission to the fetus, may lead to fetal anemia, miscarriage, non immune hydrops fetalis or even fetal death in utero (Young and Brown, 2004). Many researchers demonstrated the association of Par.B19 infection in pregnant women with birth defect and pregnancy loss (Adam et al., 2014; De Jong et al., 2011; Enders et al., 2010)Non-significant seroprevalence of positive Par.B19 immunoglobulin in the present study was found in the age group 27-34 years, while in the study done by (Al-Buhtori, 2015), the prevalence rate of positive parB19 IgG and for IgM were found in age group 22-26 years and 27-31 year, respectively, this difference may due to study design. (Zajkowska et al., 2015), concluded that the pregnant women with Par. B19 infection at the $1^{\text {st }}$ trimester consider as a significant hazard to the fetus during development, and as a cause of spontaneous abortion. In current study, the mean value of number of abortion with positive Par. B19 IgG and IgM revealed differences compared to negative Par. B19 IgG and IgM, and prevalence of positive Par. B19 immunoglobulin at the $1^{\text {st }}$ trimester, Thus the virus could be consider as one of the causes of spontaneous abortion at the early gestational period, which concordant with result of Zajkowska and his colleagues. This study shows non-significant prevalence of ACL and significant prevalence of APL found in aborted women in the age group 27-34. Study done by (Kalra et al., 2011) 
revealed significant prevalence of antibodies in the age group 22-35. While Al-Husynee (2008) observed significant prevalence of ACL and APL in aborted women in the age group 24-32.

From the studies, concluded that the presence ACL and APL in aborted women not related to age, but related to other factors like infection. In our study, women with experienced spontaneous abortion have non-significant positive prevalence of ACL and significant positive prevalence of APL compared with control groups, this result consisted with studies done by (Nizamani et al., 2015) which observed elevation of APL antibodies in women with history of pregnancy loss. (Velayuthaprabhu and Archunan, 2005) observed that the APL and ACL are important factor for abortion, and associated closely with number of pregnancy loss. (Ornoy et al., 2003) disagreed with fact that APL and ACL are associated closely with a number of pregnancy loss, but still is a causative agent for pregnancy loss, In our study, we found the prevalence of positive prevalence of ACL and APL IgM in women with experienced 1-2 abortion, followed by 3-4 abortion, This finding is in concordance with the result of Ornoy and coworker. Non-significant positive prevalence of ACL and APL IgM in current study found at the $1^{\text {st }}$ trimester of gestational period that may be responsible for spontaneous abortion. Similar to our finding, (Kalra et al., 2002) revealed an elevated level of ACL and APL IgM in aborted women at the $1^{\text {st }}$ trimester, while (Akhlaghi et al., 2013) concluded that the ACL and APL based on the number of abortion and the gestational age of abortions were increased. In our result non-significant differences was found between mean value of the number of spontaneous abortion between age groups, and an increased mean value in the number of abortion found in older age women (age >35), similar to the result of Jahromi and Husseini, 2008, which observed high number of abortion in older age women.

\section{CONCLUSIONS}

Infection with Par.B19 induced production of APL IgM. Elevated serum concentration of immunological markers like, ACL and APL were associated with pregnancy loss. The most susceptible age for abortion incidence was between age group 27-34 years and the highest frequency of abortion was found in women having abortion at first trimester.

\section{REFERENCES}

Adam, O.; Makkawi, T.; Reber, U.; Kirberg, H. (2014). The seroprevalence of parvovirus B19 infection in pregnant women in Sudan. Epidemiol. Infect, 143 (2), 242-248.

Akhlaghi, F.; Keramati, M.R.; Tafazoli, M. (2013). Study on antiphospholipid/anticardiolipin antibodies in women with recurrent abortion. Iran. Red. Crescent. Med. J., 15 (8), 718-722.

Alanen, A.; Kahala, K.; Vahlberg, T.; Koskela, P.; Vainionpaa, R. (2005). Seroprevalence, incidence of prenatal infections and reliability of maternal history of varicella zoster virus, cytomegalovirus, herpes simplex virus and parvovirus B19 infection in South-Western Finland. Int. J. Gynaecol. Obstet., 112 (1), 50-56.

Al-Buhtori, M.M. (2015). Seroprevalence of parvovirus B19 among pregnant women in Damascus, Syria. Int. J. Pharm.Sci. Rev. Res., 30 (2), 227-229.

Al-Husynee, A.J. (2008). Assessment of anticardiolipin and antiphosphatidylserine antibodies in women with recurrent abortion. Ann Coll Med Mosul.34 (1),54-57.

Al-Taei A.A.; Abdullah B.A.; Al- Attar M.Y. (2018). Serological and molecular comparison study for diagnosis of cytomegalovirus infection in aborted pregnant women in iraq. Raf. J. Sci., 27 (4), 81-89.

Baltaci, V.; Baltaci, E. (2016). Genetic aspects of recurrent miscarriage. (JSIVF).1(1),1001-1006. 
Chisaka, H.; Ito, K.; Niikura, H.; Sugawara, J.I.; Takano, T.; Murakami, T. (2006). Clinical manifestations and outcome of parvovirus $\beta 19$ infection during pregnancy in Japan. Tohoku J. Exp Med. 209 (4),277-283.

Chopra, S.; Arora, U.; Aggarwal, A. (2004). Prevalence of IgM antibodies to toxoplasma, rubella and cytomegalovirus infections during pregnancy. J. Med Educ Res., 6 (4),190-192.

Christiansen, O.B.; Steffensen, R; Nielsen, H. S.; Varming,K.; Josey, G. (2008). Multifactorial etiology of recurrent miscarriage and its scientific and clinical implications. GOI., 66(5),257-267.

Clark, C.A.; Laskin, C.A.; Spitzer, K.A. (2012). Anticardiolipin antibodies and recurrent early pregnancy loss: A century of equivocal evidence. Hum Reprod, 18(5),474-484.

De Jong, E.P.; Walther, F.J.; Kroes, A.C.M.; Oepkes, D. (2011). Parvovirus B19 infection in pregnancy: New insights and management. Prenatl Diagn, 31(5),419-425.

Enders, M.; Klingel, K.; Weidner, A.; Baisch, C.; Kandolf, R.; Schalasta, G. (2010). Risk of fetal hydrops and nonhydropic late intrauterine fetal death after gestational parvovirus B19 infection. J. Clin. Viro., 49(3),163-168

Jahromi, B.N.; Husseini, Z. (2008). Pregnancy outcome at maternal age 40 and older. Taiwan J. Obstets Gynaecol, 47 (3),318-321.

Harel, M.; Aron-Maor, A.; Sherer, Y.; Blank, M.; Shoenfeld, Y. (2005).The infectious etiology of the antiphospholipid syndrome: Links between infection and autoimmunity. Immunobiology, 210 (10),743-747.

Kalra, S.; Tuli, A.; Goyal, U.; Choudhary, R.; Raheja, S. (2002). Correlation of anticardiolibin antibody IgM with first trimester recurrent abortion. J. Anat Soc India, 51 (1),10-13.

Kalra, S.; Tuli, A.; Raheja, S.; Choudhary, R. (2011). Comparative study to evaluate the anticardiolipin antibody $\mathrm{IgG}$ in pregnant and non-pregnant women with first trimester recurrent abortion. JIMSA, 24(2), 57-58.

Mackay, I.R.; Rose, N.R.; Diamond, B.; Davidson, A. (2014). "Encyclopedia of Medical Immunology: Autoimmune diseases". Springer.

Nizamani, G.S.; Memon, R.A.; Kazi, N.; Khoharo, H.K.; Kazi, S. (2015). Anticardiolipin antibodies in women having recurrent spontaneous abortion. Pak. J. Physiol, 11(3),38-39.

Ornoy, A.; Yacobi, S.; Matalon, S.T., Blank, M.; Blumenfeld, Z.; Miller, R.K. (2003). The effects of antiphospholipid antibodies obtained from women with SLE/APS and associated pregnancy loss on rat embryos and placental explants in culture. Lupus, 12(7),573-578.

Pokale, Y.S.; Khadke, P. (2016). Risk of recurrent miscarriage in India and the effect of paternal age and maternal age. IJAS, 3(3),459-468.

Pizzo, J.D. (2011). Focus on Diagnosis, congenital infections (TORCH). Pediatr Rev. 32(12), 537-542.

Silasi, M.; Cardenas, I.; Racicot, K.; Kwon, J.; Aldo, P.; Mor, G. (2015). Viral infections during pregnancy. Am J. Reprod Immunol. 17(3),199-213.

Velayuthaprabhu, S.; Archunan, G. (2005). Evaluation of anticardiolipin antibodies and antiphosphotidyle serine antibodies in women with recurrent abortion. Indian J. Med Sci., 59 (8),347-352.

Young, N.S.; Brown, K.E. (2004).Mechanisms of disease parvovirus B19. N Engl J. Med. 350 (6),586597.

Khabat, Z.; Salih, A.; Almarzany, L. (2012). The role of leptin and insulin hormones in the pregnant women serum infected of diabetic mellitus and its histological structure effects on the placenta and umbilical cord in Erbil city. Raf. J. Sci., 23 (5), 38-49. 
Zajkowska, A.; Garkowski, A.; Czupryna, P.; Moniuszko, A.; Krol, M.E.; Szamatowicz, J. (2015). Seroprevalence of parvovirus B19 antibodies among young pregnant women or planning pregnancy, tested for toxoplasmosis. Przegl Epidemiol, 69 (3),479-482.

\title{
علاقة المناعة الذاتية والعدوى الفايروسية بارفوفيروس B19 لاى النساء ذوات الإجهاض التلقائي في ارييل العرلق
}

\begin{abstract}
الملخص
أجريت الدراسة بين كانون الثاني لسنة 2016 وكانون الثاني لسنة 2017 في مسنتفى الولادة التعليمي في مدينة أربيل / العراق. وفقا لمعايير الإشتمال والإستبعاد، نم اختيار 140 من النساء اللاتي لديهن إجهاضات تلقائية و 40 من النساء طبيعية الحمل كمجموعة مقارنة. نم التحرى في مصل الدم عن وجود الغلوبيولين المناعي M لكارديوليبين والغلوبيولين المناعي M والغلوبيولين المناعي M وG لبارفوفيروس B19 وذلك باستخدام تقنية المناعة المرتبطة بالأنزيم. أظهرت الدراسة ان الأنتشار الأيجابي لكل من الغلوبيولين المناعي M و M لكارديوليبين والغلوبيولين المناعي M لبارفوفيروس B19 لبيبيد والغلوبيولين المناعي لدى النساء المجهضات كان أعلى مما لوحظ في النساء غير المجهضات (المجموعة المقارنة). كما بينت النتائج بأن الفئه العمريه 34 27- سنة كانت لديهن اجهاضات تلقائية أكثر تكرارا من بقيه الفئات. وأن الاجهاض التلقائي لمرة او مرتين كان أكثر تكرارا لديهن في بي بهاء التلث الأول من الحمل.
\end{abstract}

الكلمات الدالة : العدوى الفايروسية بارفوفيروس، تقنية المناعة المرتبطة بالأنزيم، الكارديوليبين،الفوسفوليبيد، المناعة الذاتية. 